\title{
Activity of alcohol dehydrogenase isoenzymes and aldehyde dehydrogenase in sera of patients with hepatitis C
}

Wojciech Jelski ${ }^{1}$, Anna Strumnik$^{2}$, Karolina Orywal ${ }^{1}$, Tadeusz W. Lapinski ${ }^{3}$, Magdalena Swiderska $^{3}$, Maciej Szmitkowski ${ }^{1}$

\author{
${ }^{1}$ Department of Biochemical Diagnostics, Medical University of Bialystok, Bialystok, \\ Poland \\ ${ }^{2}$ Medical Analysis Laboratory ALAB, Warsaw, Poland \\ ${ }^{3}$ Department of Infectious Diseases and Hepatology, Medical University of Bialystok, \\ Bialystok, Poland
}

Submitted: 18 June 2015

Accepted: 30 September 2015

Arch Med Sci 2018; 14, 2: 281-287

DOI: 10.5114 /aoms.2016.60406

Copyright (C) 2016 Termedia \& Banach

\begin{abstract}
Introduction: The changes of enzyme activity in the hepatocytes in the course of different liver diseases are reflected by increase of the corresponding enzyme activity in the plasma. For example, the activities of alcohol dehydrogenase $(A D H)$ and aldehyde dehydrogenase $(A L D H)$ correlate with the severity of the condition during cirrhosis. In this study we measured the activity of ADH isoenzymes and ALDH in the sera of patients with hepatitis C. Material and methods: Serum samples were taken from 60 patients suffering from viral hepatitis $C$ and from 66 control subjects. Total ADH activity and class III and IV isoenzymes were measured by the photometric method and ALDH activity, ADH I and II by the fluorometric method.

Results: The ADH activity was significantly higher in patients with hepatitis C than in healthy $(p<0.001)$. The total activity of ADH was $1284 \mathrm{mU} / \mathrm{l}$ in patients, and $745 \mathrm{mU} / \mathrm{l}$ (controls). The activity of isoenzymes classes ADH I and $\mathrm{ADH}$ II in the hepatitis $\mathrm{C}$ group increased respectively $55 \%$ (4.24 vs. $1.88 \mathrm{mU} / \mathrm{l} ; p<0.001)$ and $47 \%$ (26.63 vs. $14.11 \mathrm{mU} / \mathrm{l} ; p<0.001)$ in the comparison to the control. There was significant increase in the activity of ADH I isoenzyme (4.96 vs. $3.81 \mathrm{mU} / \mathrm{l} ; p<0.001)$ and ADH total (1833 vs. $1105 \mathrm{mU} / \mathrm{l} ; p<0.001)$ in patients with high viral load in comparison to patients with low viral load.

Conclusions: The activity of class I and II ADH isoenzymes in the sera of patients with hepatitis $C$ is increased, and it seems to be caused by the release of these isoenzymes from damaged liver cells.
\end{abstract}

Key words: alcohol dehydrogenase isoenzymes, aldehyde dehydrogenase, hepatitis C.

\section{Introduction}

Hepatitis C virus (HCV) is an RNA virus classified in the Flaviviridae virus family. Worldwide, one hundred and seventy million individuals are infected with $\mathrm{HCV}$, with an incidence rate of $3 \%$. Hepatitis $\mathrm{C}$ virus infections represent a major global public health problem. Hepatitis $C$ virus-related chronic hepatitis are the main causes of cirrhosis and hepatocellular carcinoma (HCC), which are responsible for high rates of morbidity and mortality [1, 2].

\author{
Corresponding author: \\ Wojciech Jelski MD \\ Department \\ of Biochemical Diagnostics \\ Medical University \\ 15 A Waszyngtona St \\ 15-69 Bialystok, Poland \\ Phone: +48 857468587 \\ Fax: +48 857468585 \\ E-mail:wjelski@umb.edu.pl
}


It is commonly accepted that cellular injury and necrosis of hepatocytes leads to the release of cytoplasmic enzymes. According to the data obtained by Chrostek and Szmitkowski, the elevated serum activity of alcohol dehydrogenase $(\mathrm{ADH})$ reflects damage of liver parenchymal cells, especially in the course of acute viral hepatitis $B$ and cirrhosis [3, 4]. Their results demonstrate that the activity of ADH isoenzyme can be a useful marker of liver damage in the course of viral hepatitis B. Alcohol dehydrogenase and aldehyde dehydrogenase $(A L D H)$ are principal enzymes catalyzing the conversion of ethanol to acetate. Alcohol dehydrogenase comprises a family of enzymes which has been grouped into several classes. In humans, the first two classes are mainly located in the liver cells. Class I ADH is the classical liver alcohol dehydrogenase, but it is also observed in lesser amounts in the gastrointestinal tract, lungs, and kidneys [5]. Class II isoenzyme of $A D H$ is found only in the liver, whereas class III is present in all examined tissues [6]. Class IV ADH is expressed preferably in the upper part of the digestive tract [7]. In humans, liver aldehyde dehydrogenase exists as several isoenzymes which differ in their subcellular location and kinetic properties. These isoenzymes are usually divided into two broadly defined groups, cytosolic high $\mathrm{K}_{\mathrm{m}} \mathrm{ALDH}$ and mitochondrial low $\mathrm{K}_{\mathrm{m}} \mathrm{ALDH}$, based on their Michaelis constant for acetaldehyde [8].

We hypothesize that the changed activities of $\mathrm{ADH}$ and ALDH in damaged hepatocytes in the course of chronic hepatitis $\mathrm{C}(\mathrm{CHC})$ are reflected in the plasma. In the present study, we investigated the effect of liver cell inflammation in hepatitis $C$ on the serum activity of alcohol dehydrogenase isoenzymes and aldehyde dehydrogenase.

\section{Material and methods}

\section{Patients}

The protocol was approved by the Human Care Committee of the Medical University in $\mathrm{Bi}$ alystok, Poland (approval no. R-I-002/572/2013). All patients gave informed consent for the examination.

Serum samples were taken for routine biochemical investigations from 60 patients suffering from viral hepatitis C (38 males and 22 females, mean age 44 years, range: $20-72$ years) hospitalized in the Department of Infectious Diseases and Hepatology University Hospital, Medical University of Bialystok (Poland). Hepatitis was histopathologically confirmed in each case, with HCV infection diagnosed by molecular biology techniques (quantitative RT PCR for viral load determination) and sequence-specific RT PCR with reverse hybrid- ization for genotype. Disease activity grade and fibrosis stage were quantitatively scored according to the METAVIR classification (grade 1 was found in 21 patients, grade 2 in 15 patients, grade 3 in 12 patients, and grade 4 in 12 patients). For the analysis patients were divided into two groups: 44 patients with genotype $1 \mathrm{~b}$ and 16 patients with genotype $3 a$. Patients were stratified according to baseline viral load (31 patients with $\leq 600,000$ IU/ $\mathrm{ml}$ and 29 patients with $>600,000 \mathrm{IU} / \mathrm{ml}$ ).

Patients were excluded if they had coinfection with human immunodeficiency virus or hepatitis B, or any other cause of liver disease. Alcohol consumption was assessed using a validated questionnaire. Before the examinations all patients had not consumed alcohol for almost 1 year.

The control group comprised 66 volunteers (36 men and 30 women, aged $25-70$ years). The healthy controls were recruited from the same geographical location and ethnic populations as the patients and were not from the hospital. Control groups were selected from healthy community residents who attend the hospitals for routine physical check-ups at the Department of Preventive Medicine. Control subjects were volunteers and were defined as those with normal results of all physical and blood examinations. All persons of the control group drank alcohol occasionally and self-reported an intake of $<25 \mathrm{~g}$ of ethanol per week. None of them consumed any drug.

\section{Biochemical assays}

\section{Determination of total ADH activity}

Total ADH activity was estimated by the photometric method with p-nitrosodimethylaniline (NDMA) as a substrate [9]. The reaction mixture $(2 \mathrm{ml})$ contained $0.1 \mathrm{ml}$ of serum and $1.8 \mathrm{ml}$ of a $26 \mu \mathrm{M}$ solution of substrate in $0.1 \mathrm{M}$ of sodium phosphate buffer, $\mathrm{pH} 8.5$ and $0.1 \mathrm{ml}$ of a mixture containing $0.25 \mathrm{M} n$-butanol and $5 \mathrm{mM}$ NAD. The reduction of NDMA was monitored at $440 \mathrm{~nm}$ on a Shimadzu UV/VIS 1202 spectrophotometer (Shimadzu Europa $\mathrm{GmbH}$, Duisburg, Germany).

\section{Determination of total ALDH activity}

ALDH activity was measured using the fluorogenic method based on the oxidation of 6-methoxy-2-naphthaldehyde to the fluorescent 6-methoxy-2 naphthoate [10]. The reaction mixture contained $60 \mu \mathrm{l}$ of serum, $60 \mu$ of substrate, $20 \mu \mathrm{l}$ of $11.4 \mathrm{mM} \mathrm{NAD}$ and $2.8 \mathrm{ml}$ of $50 \mathrm{mM}$ sodium phosphate buffer, $\mathrm{pH}$ 8.5. The mixture also contained $50 \mu \mathrm{l}$ of a $12 \mathrm{mM}$ solution of 4-methylpyrazole as a specific inhibitor of ADH activity. The fluorescence was read at an excitation wavelength of $310 \mathrm{~nm}$ and emission wavelength of $360 \mathrm{~nm}$. 


\section{Determination of class I and II ADH} isoenzymes

Class I and II alcohol dehydrogenase isoenzyme activity was measured using fluorogenic substrates (4-methoxy-1-naphthaldehyde for class I and 6-methoxy-2-naphthaldehyde for class II) in a reduction reaction according to Wierzchowski et al. [11]. The assays were performed in a reaction mixture containing serum $(60 \mu \mathrm{l})$, substrate $(150 \mu \mathrm{l}$ of $300 \mu \mathrm{M}), \mathrm{NADH}(100 \mu \mathrm{l}$ of $1 \mathrm{mM})$ and $0.1 \mathrm{M}$ of sodium phosphate buffer, $\mathrm{pH} 7.6$ $(2.69 \mathrm{ml})$ in conditions previously described [12]. The measurements were performed on a Shimadzu RF-5301 spectrofluorophotometer (Shimadzu Europa GmbH, Duisburg, Germany) at an excitation wavelength of $316 \mathrm{~nm}$ for both substrates and emission of $370 \mathrm{~nm}$ for class I and $360 \mathrm{~nm}$ for class II isoenzymes.

\section{Determination of class III ADH isoenzyme}

The assay mixture for class III alcohol dehydrogenase activity contained serum $(100 \mu \mathrm{l}), n$-octanol as a substrate $(31 \mu \mathrm{l}$ of $1 \mathrm{mM}), \operatorname{NAD}(240 \mu \mathrm{l}$ of $1.2 \mathrm{mM}$ ) in 0.1 M NaOH-glycine buffer, pH 9.6 [13]. The reduction of NAD was monitored at $340 \mathrm{~nm}$ and at $25^{\circ} \mathrm{C}$ on a Shimadzu UV/VIS 1202 spectrophotometer.

\section{Determination of class IV ADH isoenzyme}

The assay mixture for class IV alcohol dehydrogenase activity contained serum $(50 \mu \mathrm{l})$, $m$-nitrobenzaldehyde as a substrate of $(132 \mu \mathrm{l}$ of $80 \mu \mathrm{M}), \mathrm{NADH}(172 \mu \mathrm{l}$ of $86 \mu \mathrm{M})$ in $0.1 \mathrm{M}$ sodium phosphate buffer, $\mathrm{pH} 7.5[14,15]$. The oxidation of $\mathrm{NADH}$ was monitored at $340 \mathrm{~nm}$ and at $25^{\circ} \mathrm{C}$ on a Shimadzu UV/VIS 1202 spectrophotometer.

\section{Statistical analysis}

A preliminary statistical analysis ( $\chi^{2}$ test) revealed that the distribution of ADH and ALDH activities did not follow a normal distribution. Con- sequently, Wilcoxon's test was used for statistical analysis. Data are presented as median, range and mean values. Statistically significant differences were defined as comparisons resulting in $p<0.05$.

\section{Results}

The activities of alcohol dehydrogenase, aldehyde dehydrogenase and isoenzymes of alcohol dehydrogenase in the sera are presented in Table I. The total activity of alcohol dehydrogenase was significantly higher in patients with hepatitis $C$ than in healthy subjects (about $72 \%$ ). The median total activity of ADH was $1284 \mathrm{mU} / \mathrm{l}$ in patients, and $745 \mathrm{mU} / \mathrm{I}$ in controls. The analysis of ALDH activity did not reveal a significant difference between the tested group and healthy controls.

The comparison of ADH isoenzyme activities showed a large difference for class I and II ADH. The median activity of these classes of isoenzymes in the hepatitis $C$ group increased by about $125 \%$ (4.24 vs. $1.88 \mathrm{mU} / \mathrm{l}$ ) and 89\% (26.63 vs. $14.11 \mathrm{mU} / \mathrm{l})$ respectively in the comparison to the control level. This increase was statistically significant $(p<0.001)$. The other tested classes of ADH isoenzymes had higher activities in the serum of patients with hepatitis $C$, but the differences were not statistically significant in all patient groups $(p>0.05)$.

The analysis of $A D H, A L D H$ and $A D H$ isoenzyme activities in the serum did not reveal significant differences between patients with hepatitis $C$ virus genotype $1 \mathrm{~b}$ and $3 a$ (Table $\mathrm{II}$ ).

Patients with a high baseline viral load (> $600000 \mathrm{lU} / \mathrm{ml}$ ) had a significantly higher total activity of alcohol dehydrogenase than patients with lower viraemia (Table III). Total ADH activity significantly differed between these groups and the control group. In contrast, the analysis of ALDH activity did not show a significant difference between patients with high viraemia, low viraemia and controls. Significantly higher class I ADH activity was found in the sera of patients with a high viral load $(4.96 \mathrm{mU} / \mathrm{l})$ in comparison to patients

Table I. Alcohol dehydrogenase and aldehyde dehydrogenase activity in sera of patients with hepatitis C

\begin{tabular}{|c|c|c|c|c|c|c|}
\hline $\begin{array}{l}\text { Tested } \\
\text { group }\end{array}$ & $\begin{array}{l}\text { ADH I } \\
\text { Median } \\
\text { Range } \\
\text { Mean }\end{array}$ & $\begin{array}{l}\text { ADH II } \\
\text { Median } \\
\text { Range } \\
\text { Mean }\end{array}$ & $\begin{array}{l}\text { ADH III } \\
\text { Median } \\
\text { Range } \\
\text { Mean }\end{array}$ & $\begin{array}{l}\text { ADH IV } \\
\text { Median } \\
\text { Range } \\
\text { Mean }\end{array}$ & $\begin{array}{l}\text { ADH total } \\
\text { Median } \\
\text { Range } \\
\text { Mean }\end{array}$ & $\begin{array}{c}\text { ALDH total } \\
\text { Median } \\
\text { Range } \\
\text { Mean }\end{array}$ \\
\hline $\begin{array}{l}\text { Hepatitis C } \\
(n=60)\end{array}$ & $\begin{array}{c}4.24 \\
1.14-0.53 \\
4.03\end{array}$ & $\begin{array}{c}26.63 \\
10.25-41.47 \\
26.40\end{array}$ & $\begin{array}{c}11.52 \\
7.05-18.68 \\
11.27\end{array}$ & $\begin{array}{c}5.61 \\
2.86-11.98 \\
5.33\end{array}$ & $\begin{array}{c}1284 \\
392-2704 \\
1233\end{array}$ & $\begin{array}{c}3.18 \\
1.62-6.85 \\
2.99\end{array}$ \\
\hline $\begin{array}{l}\text { Control } \\
(n=66)\end{array}$ & $\begin{array}{c}1.88 \\
0.91-3.57 \\
1.71\end{array}$ & $\begin{array}{c}14.11 \\
5.44-21.05 \\
13.72\end{array}$ & $\begin{array}{c}11.15 \\
6.84-18.16 \\
10.88\end{array}$ & $\begin{array}{c}5.22 \\
2.49-11.48 \\
5.08\end{array}$ & $\begin{array}{c}745 \\
318-2246 \\
716\end{array}$ & $\begin{array}{c}2.93 \\
1.46-6.2 \\
2.84\end{array}$ \\
\hline & $p<0.001^{*}$ & $p<0.001^{*}$ & $p=0.327$ & $p=0.473$ & $p<0.001^{*}$ & $p=0.527$ \\
\hline
\end{tabular}

$A D H$ - alcohol dehydrogenase, ALDH - aldehyde dehydrogenase. Data are expressed as $m U / l ;{ }^{*}$ statistically significant differences between groups, $p$ - hepatitis $C$ vs. control. 
Table II. Alcohol dehydrogenase and aldehyde dehydrogenase activity in sera of patients with hepatitis C virus genotype $1 b$ and $3 a$

\begin{tabular}{|c|c|c|c|c|c|c|}
\hline $\begin{array}{l}\text { Tested } \\
\text { group }\end{array}$ & $\begin{array}{l}\text { ADH I } \\
\text { Median } \\
\text { Range } \\
\text { Mean }\end{array}$ & $\begin{array}{l}\text { ADH II } \\
\text { Median } \\
\text { Range } \\
\text { Mean }\end{array}$ & $\begin{array}{l}\text { ADH III } \\
\text { Median } \\
\text { Range } \\
\text { Mean }\end{array}$ & $\begin{array}{l}\text { ADH IV } \\
\text { Median } \\
\text { Range } \\
\text { Mean }\end{array}$ & $\begin{array}{l}\text { ADH total } \\
\text { Median } \\
\text { Range } \\
\text { Mean }\end{array}$ & $\begin{array}{l}\text { ALDH total } \\
\text { Median } \\
\text { Range } \\
\text { Mean }\end{array}$ \\
\hline $\begin{array}{l}\text { Genotype } 1 b \\
(n=44)\end{array}$ & $\begin{array}{c}4.31 \\
1.32-6.53 \\
4.12\end{array}$ & $\begin{array}{c}26.86 \\
10.62-41.47 \\
26.61\end{array}$ & $\begin{array}{c}11.77 \\
7.41-18.68 \\
11.38\end{array}$ & $\begin{array}{c}5.74 \\
2.97-11.98 \\
5.53\end{array}$ & $\begin{array}{c}1306 \\
454-2704 \\
1283\end{array}$ & $\begin{array}{c}3.29 \\
1.78-6.85 \\
3.14\end{array}$ \\
\hline $\begin{array}{l}\text { Genotype } 3 a \\
(n=16)\end{array}$ & $\begin{array}{c}4.18 \\
1.14-6.04 \\
4.12\end{array}$ & $\begin{array}{c}26.44 \\
10.25-40.54 \\
26.31\end{array}$ & $\begin{array}{c}11.43 \\
7.05-18.05 \\
11.06\end{array}$ & $\begin{array}{c}5.48 \\
2.86-11.60 \\
5.31\end{array}$ & $\begin{array}{c}1275 \\
392-2611 \\
1248\end{array}$ & $\begin{array}{c}3.07 \\
1.62-6.22 \\
2.81\end{array}$ \\
\hline & $p=0.448$ & $p=0.548$ & $p=0.385$ & $p=0.426$ & $p=0.404$ & $p=0.545$ \\
\hline
\end{tabular}

Table III. Alcohol dehydrogenase and aldehyde dehydrogenase activity in sera of patients with hepatitis $C$ depending on viral load

\begin{tabular}{|c|c|c|c|c|c|c|}
\hline $\begin{array}{l}\text { Tested } \\
\text { group }\end{array}$ & $\begin{array}{l}\text { ADH I } \\
\text { Median } \\
\text { Range } \\
\text { Mean }\end{array}$ & $\begin{array}{l}\text { ADH II } \\
\text { Median } \\
\text { Range } \\
\text { Mean }\end{array}$ & $\begin{array}{l}\text { ADH III } \\
\text { Median } \\
\text { Range } \\
\text { Mean }\end{array}$ & $\begin{array}{l}\text { ADH IV } \\
\text { Median } \\
\text { Range } \\
\text { Mean }\end{array}$ & $\begin{array}{l}\text { ADH total } \\
\text { Median } \\
\text { Range } \\
\text { Mean }\end{array}$ & $\begin{array}{c}\text { ALDH total } \\
\text { Median } \\
\text { Range } \\
\text { Mean }\end{array}$ \\
\hline $\begin{array}{l}\text { Viral load } \\
>600000 \mathrm{lU} / \mathrm{ml} \\
(n=29)\end{array}$ & $\begin{array}{c}4.96 \\
1.65-6.53 \\
4.68\end{array}$ & $\begin{array}{c}27.08 \\
10.96-41.47 \\
26.77\end{array}$ & $\begin{array}{c}11.88 \\
7.46-18.68 \\
11.60\end{array}$ & $\begin{array}{c}5.79 \\
2.92-11.98 \\
5.68\end{array}$ & $\begin{array}{c}1833 \\
675-2704 \\
1746\end{array}$ & $\begin{array}{c}3.35 \\
1.83-6.85 \\
3.16\end{array}$ \\
\hline $\begin{array}{l}\text { Viral load } \\
\leq 600000 \mathrm{lU} / \mathrm{ml} \\
(n=31)\end{array}$ & $\begin{array}{c}3.81 \\
1.14-6.08 \\
3.72\end{array}$ & $\begin{array}{c}26.35 \\
10.25-41.01 \\
26.416\end{array}$ & $\begin{array}{c}11.36 \\
7.05-18.11 \\
11.14\end{array}$ & $\begin{array}{c}5.50 \\
2.86-11.35 \\
5.28\end{array}$ & $\begin{array}{c}1105 \\
392-2466 \\
1044\end{array}$ & $\begin{array}{c}3.11 \\
1.62-6.40 \\
2.85\end{array}$ \\
\hline $\begin{array}{l}\text { Control } \\
(n=66)\end{array}$ & $\begin{array}{c}1.88 \\
0.91-3.57 \\
1.71\end{array}$ & $\begin{array}{c}14.11 \\
5.44-21.05 \\
13.72\end{array}$ & $\begin{array}{c}11.15 \\
6.84-18.16 \\
10.88\end{array}$ & $\begin{array}{c}5.22 \\
2.49-11.48 \\
5.08\end{array}$ & $\begin{array}{c}745 \\
318-2246 \\
716\end{array}$ & $\begin{array}{c}2.93 \\
1.46-6.2 \\
2.84\end{array}$ \\
\hline & $\begin{array}{l}p^{a}<0.001^{*} \\
p^{b}<0.001^{\star} \\
p^{c}<0.001^{*}\end{array}$ & $\begin{array}{l}p^{a}<0.001^{\star} \\
p^{b}<0.001^{\star} \\
p^{c}=0.285\end{array}$ & $\begin{array}{l}p^{a}=0.513 \\
p^{b}=0.365 \\
p^{c}=0.416\end{array}$ & $\begin{array}{l}p^{a}=0.438 \\
p^{b}=0.387 \\
p^{c}=0.422\end{array}$ & $\begin{array}{l}p^{a}<0.001^{*} \\
p^{b}<0.001^{*} \\
p^{c}<0.001^{\star}\end{array}$ & $\begin{array}{l}p^{a}=0.512 \\
p^{b}=0.546 \\
p^{c}=0.453\end{array}$ \\
\hline
\end{tabular}

$A D H$ - alcohol dehydrogenase, $A L D H$ - aldehyde dehydrogenase. Data are expressed as $m U / l$. *Statistically significant differences between groups, $p^{a}-$ viral load $>600000 \mathrm{lU} / \mathrm{ml}$ vs. control, $p^{b}-$ viral load $\leq 600000 \mathrm{IU} / \mathrm{ml}$ vs. control, $p^{c}-$ viral load $>600000 \mathrm{IU} / \mathrm{ml}$ vs. viral load $\leq 600000 \mathrm{lU} / \mathrm{ml}$

with a low load (3.81 $\mathrm{mU} / \mathrm{l})$. The ADH I and ADH II activity was significantly higher regardless of the viraemia compared with the control. The analysis of ADH III and IV activity did not show a significant difference between patients with high viraemia, low viraemia and control.

Having analyzed activity of particular ADH isoenzymes depending on the progression stage of the fibrosis (Table IV) significantly higher the ADH class I and II activities were found in the hepatitis $C$ patients regardless of stage in comparison to the control group $(p<0.05)$. Significantly higher ADH class I and II activities were found in the hepatitis $C$ patients regardless of stage in comparison to the control group $(p<0.05)$. The other isoenzymes did not exhibit any marked changes of activity among patients at various advancing stages of fibrosis. The serum level of total ADH activity was significantly higher in the tested group (each stage) than the control group. ALDH shows no significant difference in activity depending on the degree of liver damage.

\section{Discussion}

In the last few years, considerable progress has been made in the knowledge of epidemiology and factors influencing the course of hepatitis C. Still, important efforts are needed for screening for early diagnosis in order to improve the treatment of patients with chronic hepatitis C [1]. Diagnostics of $\mathrm{CHC}$ in the early stage is usually difficult as the disease is normally asymptomatic. The majority of HCV-infected patients have no hepatic symptoms, whereas the extrahepatic manifestations may be the reason that they seek medical care and thus have a chance to be investigated, diagnosed and finally properly treated [16]. Therefore it is very important to find markers that detect hepatocellular damage as soon as possible, and for a long time there have been attempts to achieve this. Some authors have studied various substances as markers of hepatitis C. For example, Ciesla et al. reported that Met-enkephalin concentration measurement in the liver tissue seems to be a useful method for differentiation of stage 2 from stages 3 and 4 
Table IV. Alcohol dehydrogenase and aldehyde dehydrogenase activity in sera of patients with hepatitis $\mathrm{C}$ depending on fibrosis stage

\begin{tabular}{|lcccccc|}
\hline Tested & ADH I & ADH II & ADH III & ADH IV & ADH total & ALDH total \\
group & Median & Median & Median & Median & Median & Median \\
& Range & Range & Range & Range & Range & Meange \\
& Mean & Mean & Mean & Mean & Mean \\
\hline Grade 1 & 4.01 & 26.13 & 11.28 & 5.39 & 1204 & 3.02 \\
$(n=21)$ & $1.14-5.74$ & $10.25-39.84$ & $7.05-18.02$ & $2.86-11.17$ & $392-2526$ & $1.62-6.25$ \\
& 3.92 & 25.77 & 11.01 & 5.05 & 1178 & 2.84 \\
\hline Grade 2 & 4.22 & 26.39 & 11.46 & 5.52 & 1256 & 3.15 \\
$(n=15)$ & $1.55-6.08$ & $10.84-40.08$ & $7.48-18.30$ & $3.09-11.46$ & $467-2612$ & $1.81-6.64$ \\
& 4.16 & 26.18 & 11.22 & 5.44 & 1240 & 3.06 \\
\hline Grade 3 & 4.35 & 26.65 & 11.60 & 5.75 & 1291 & 3.33 \\
$(n=12)$ & $1.82-6.41$ & $11.21-41.13$ & $7.66-18.47$ & $3.40-11.69$ & $488-2674$ & $1.90-6.68$ \\
& 4.28 & 26.47 & 11.46 & 5.62 & 1265 & 3.20 \\
\hline Grade 4 & 4.46 & 26.89 & 11.81 & 5.83 & 1315 & 3.36 \\
$(n=12)$ & $1.95-6.53$ & $11.66-41.47$ & $8.12-18.68$ & $3.99-11.98$ & $544-2704$ & $1.94-6.85$ \\
& 4.37 & 26.74 & 11.76 & 5.71 & 1296 & 3.28 \\
\hline Control & 1.88 & 14.11 & 11.15 & 5.22 & 745 & 2.93 \\
$(n=66)$ & $0.91-3.57$ & $5.44-21.05$ & $6.84-18.16$ & $2.49-11.48$ & $318-2246$ & $1.46-6.2$ \\
& 1.71 & 13.72 & 10.88 & 5.08 & 716 & 2.84 \\
\hline & $p^{a}<0.001^{*}$ & $p^{a}<0.001^{*}$ & $p^{a}=0.426$ & $p^{a}=0.417$ & $p^{a}<0.001^{*}$ & $p^{a}=0.558$ \\
& $p^{b}<0.001^{*}$ & $p^{b}<0.001^{*}$ & $p^{b}=0.387$ & $p^{b}=0.343$ & $p^{b}<0.001^{*}$ & $p^{b}=0.514$ \\
& $p^{c}<0.001^{*}$ & $p^{c}<0.001^{*}$ & $p^{c}=0.312$ & $p^{c}=0.465$ & $p^{c}<0.001^{*}$ & $p^{c}=0.443$ \\
$p^{d}<0.001^{*}$ & $p^{d}<0.001^{*}$ & $p^{d}=0.285$ & $p^{d}=0.335$ & $p^{d}<0.001^{*}$ & $p^{d}=0.422$ \\
\hline
\end{tabular}

$A D H$-alcohol dehydrogenase, $A L D H$ - aldehyde dehydrogenase. Data are expressed as $m U / l$, *statistically significant differences between groups, $p^{a}$-stage 1 vs. control, $p^{b}-$ stage 2 vs. control, $p^{c}$ - stage 3 vs. control, $p^{d}-$ stage 4 vs. control.

of severe liver fibrosis [17]. The changes in enzyme activity in the damaged hepatocytes during the course of different liver diseases are reflected by an increase in the corresponding enzyme activity in the plasma. In this study we found that the serum total alcohol dehydrogenase activity changed in the course of hepatitis $C$. The increase of total ADH activity was positively correlated with $\mathrm{ADH} I$ and

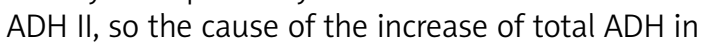
the course of this disease is an elevation of class I and II ADH isoenzymes. ADH I is also present in the gastrointestinal tract, kidneys and lungs, but up to $95 \%$ of this activity is found in the liver. Class II $\mathrm{ADH}$ is detected only in the hepatocytes. So, the elevated activity of ADH I and ADH II seems to be caused by the isoenzymes released from inflamed altered liver cells. The changes in activities of other $\mathrm{ADH}$ isoenzymes were not significant in the serum of patients with hepatitis C. Aldehyde dehydrogenase is present in the liver, although the activity of ALDH seems to be disproportionally low compared to ADH activity. The serum levels of aldehyde dehydrogenase were not significantly higher in patients with HCV infection in comparison to the healthy group. The reason for this difference in expression of $\mathrm{ADH}$ and $\mathrm{ALDH}$ in $\mathrm{CHC}$ may be disproportionately low ALDH activity in the liver compared to the activity of $A D H$ and ALDH with subcellular localization in the mitochondria. The half-lives of $A D H$ and ALDH in the serum are about 26 and $22 \mathrm{~h}$ respectively [18].

A very interesting issue is the possible influence of viral factors such as genotype and baseline vi- ral load on the activity of enzymes in the serum. In eastern and southern Europe, mainly type $1 \mathrm{~b}$ occurs. In Poland, according to a study in groups of adult patients and asymptomatic carriers, the most commonly detected genotype is $1 b, 3 a$ is detected rarely, and other genotypes of the virus are detected in individual cases [19]. In this study the genotype of the virus did not have an effect on the activity of tested enzymes. We found that the activity of ADH and ALDH in serum of patients with genotype $1 \mathrm{~b}$ did not differ from that of patients with genotype $3 a$, while the viral load had a significant effect on the activity of alcohol dehydrogenase. High viraemia is defined differently by various authors, with the most widely applied consensus being a plasma virus load of $>600000 \mathrm{lU} /$ $\mathrm{ml}[20,21]$. In our study we also adopted this level of viral load as the cut-off point. In our analysis, we found that the baseline viral load significantly affects the ADH I activity and total activity of alcohol dehydrogenase. ADH II activity did not change depending on the level of viraemia, although it was significantly higher in patients with HCV infection compared to the control group. Further multiplication of the virus does not cause an increase in the activity of this isoenzyme. This may indicate that ADH II is released faster and earlier than class I. Moreover, HCV is not only a hepatotropic pathogen; thus in the serum of patients with a high viral load ADH I may be derived from other organs [22]. Another explanation may be the fact that viruses can stimulate modification of occurring proteins 
or production of completely new enzymatic proteins similar to ADH I [23].

All noxious agents that chronically act on the liver and damage hepatic cells may eventually cause chronic hepatitis, which may in turn lead to progression of fibrosis. HCV infection is also a cause of progressive fibrosis of liver tissue. Viral hepatitis $C$ accompanied by cellular injury and necrosis leads to the release of cytoplasmic enzymes such as $\mathrm{ADH}$. This study showed that the activity of class I and II alcohol dehydrogenase in $\mathrm{CHC}$ increased in parallel with the development of the disease. We have observed a tendency towards an increase of the total ADH activity together with the progression of the hepatitis $C$. The other markers of liver lesions (bilirubin concentration, activities of aminotransferases) were also significantly elevated. The median concentration of total bilirubin was $3.95 \mathrm{mg} / \mathrm{dl}$ in patients, and $0.65 \mathrm{mg} / \mathrm{dl}$ in controls. The median activity of alanine transaminase and aspartate transaminase was respectively $360 \mathrm{U} / \mathrm{l}$ and $610 \mathrm{U} / \mathrm{l}$ in the serum of patients with hepatitis $C$ and $26 \mathrm{U} / \mathrm{l}$ and $20 \mathrm{U} / \mathrm{l}$ in healthy controls. The activity of both transaminases and alcohol dehydrogenase correlate well with the severity of the conditions, and regular monitoring can be a diagnostic marker of hepatic cell damage during chronic hepatitis $C$.

The results in the present paper are similar to other studies performed in various liver diseases. For example, Chrostek and Szmitkowski found much higher ADH I and II isoenzyme activity in the sera of patients with acute viral hepatitis B [3]. They also observed that only serum activity of class I alcohol dehydrogenase was significantly higher in chronic hepatitis B than in controls [24]. The comparison of total alcohol dehydrogenase activity in the sera of alcoholics and non-alcoholic cirrhotic patients indicates similar changes in both cases, with an evident elevation of class I and total enzyme activity [4, 25]. In our previous study we found that activity of class I alcohol dehydrogenase isoenzymes and total ADH activity was elevated in the serum of patients with metastatic liver cancer. ADH I was significantly higher in the sera of patients with metastatic tumours than in those with primary cancers [26].

In conclusion, our data indicate that the increase of the activity of class I and II alcohol dehydrogenase isoenzyme in the sera of patients with $\mathrm{HCV}$ infection seems to be caused by the release of this isoenzyme from damaged liver cells.

\section{Conflict of interest}

The authors declare no conflict of interest.

\section{References}

1. Marcellin P. Hepatitis B and hepatitis C in 2009. Liver Intern 2009; 29: 1-8.
2. Tahan V, Ozdogan O, Tozun N. Epidemiology of viral hepatitis in the Mediterranean Basin. Anal Acad Med Bial 2003; 48: 11-7.

3. Chrostek L, Szmitkowski M. Serum class I and II alcohol dehydrogenase activity during the course of viral hepatitis. Eur J Clin Chem Clin Biochem 1995; 33: 825-9.

4. Chrostek L, Szmitkowski M. Human alcohol dehydrogenase isoenzyme activity in the sera of non-alcoholic liver cirrhotic patients. Eur J Clin Chem Clin Biochem 1996; 34: 801-4.

5. Maly IP, Toranelli M, Sasse D. Distribution of alcohol dehydrogenase isoenzymes in human liver acinus. Histochem Cell Biol 1999; 111: 391-7.

6. Jelski W, Szmitkowski M. Alcohol dehydrogenase (ADH) and aldehyde dehydrogemase (ALDH) in the cancer diseases. Clin Chim Acta 2008; 395: 1-5.

7. Jelski W, Chrostek L, Szmitkowski M, Laszewicz W. Activity of class I, II, III, and IV alcohol dehydrogenase isoenzymes in human gastric mucosa. Dig Dis Sci 2002; 47: 1554-7.

8. Goedde HW, Agarwal DP. Polymorphism of aldehyde dehydrogenase and alcohol sensitivity. Enzyme 1987; 37: 29-44.

9. Skursky L, Kovar J, Stachova M. A sensitive assay for alcohol dehydrogenase activity in blood serum. Anal Biochem 1979; 89: 65-71.

10. Jelski W, Mroczko B, Szmitkowski M. The diagnostic value of alcohol dehydrogenase $(A D H)$ isoenzymes and aldehyde dehydrogenase $(\mathrm{ALDH})$ measurement in the sera of colorectal cancer patients. Dig Dis Sci 2010; 55: 2953-7.

11. Wierzchowski J, Dafeldecker WP, Holmquist B, Vallee BL. Fluorimetric assay for isozymes of human alcohol dehydrogenase. Anal Biochem 1989; 178: 57-62.

12. Jelski W, Kozlowski M, Laudanski J, Niklinski J, Szmitkowski M. The activity of class I, II, III, and IV alcohol dehydrogenase $(A D H)$ isoenzymes and aldehyde dehydrogenase $(\mathrm{ALDH})$ in esophageal cancer. Dig Dis Sci 2009; 54: 725-30.

13. Koivusalo M, Baumann M, Uotila L. Evidence for the identity of glutathione-dependent formaldehyde dehydrogenase and class III alcohol dehydrogenase. FEBS Lett 1989; 257: 105-9.

14. Dohmen K, Baraona E, Ishibashi $\mathrm{H}$, et al. Ethnic differences in gastric sigma-alcohol dehydrogenase activity and ethanol first pass metabolism. Alcohol Clin Exp Res 1996; 20: 1569-76.

15. Jelski W, Łaniewska-Dunaj M, Strumnik A, Szmitkowki M. The alcohol dehydrogenase isoenzyme alcohol dehydrogenase IV as a candidate marker of Helicobacter pylori infection. Arch Med Sci 2014; 10: 951-5.

16. Zarebska-Michaluk DA, Lebensztejn DM, Kryczka W, Skiba E. Extrahepatic manifestations associated with chronic hepatitis $C$ infections in Poland. Adv Med Sci 2010; 55: 67-73.

17. Ciesla A, Mach T, Pierzchala-Koziec K, Skwara P, Szczepański W. Met-enkephalin in the liver as a marker of hepatocellular damage in chronic viral hepatitis type B and C. Adv Med Sci 2006; 51: 261-4.

18. Matsumoto M, Cyganek I, Sanghani PC, Cho WK, Liangpunsakul S, Crabb DW. Ethanol metabolism by HeLa cells transduced with human alcohol dehydrogenase isoenzymes: control of the pathway by acetaldehyde concentration. Alcohol Clin Exp Res 2011; 35: 28-38.

19. Cocquerel L, Wychowski C, Minner F, Penin F, Dubuisson J. Charged residues in the transmembrane domains of hepatitis $C$ virus glycoproteins play a major role in 
the processing, subcellular localization, and assembly of these envelope proteins. J Virol 2000; 74: 3623-33.

20. Jurczyk K, Laurans L, Karpinska E, Wawrzynowicz-Syczewska M, Parczewski M, Boron-Kaczmarska A. Risk score based PEG interferon alpha $2 \mathrm{~b}$ and ribavirin treatment response estimation model for genotype 1 chronic hepatitis C patients. Adv Med Sci 2011; 56: 165-71.

21. Floreani A, Baldo V, Rizzotto ER, Carderi I, Baldovin T, Minola E. Pegylated interferon alpha-2b plus ribavirin for naïve patients with HCV-related cirrhosis. J Clin Gastroenterol 2008; 42: 734-7.

22. Gowans E. Distribution of markers of hepatitis C virus infection throughout the body. Sem Liv Dis 2000; 20: 85-101.

23. Nitkiewicz J. Chronic hepatitis C infection - mechanisms of virus "immune escape". Przegl Epidemiol 2004; 58: 423-33.

24. Chrostek L, Szmitkowski M. Isoenzymes of class I and II alcohol dehydrogenase in chronic hepatitis. Clin Chem Lab Med 1999; 37: 145-7.

25. Chrostek L, Szmitkowski M, Wierzchowski J. Activity of class I and II alcohol dehydrogenase in the sera of alcoholics. Eur J Clin Chem Clin Biochem 1994; 32: 881-4.

26. Jelski W, Zalewski B, Szmitkowski M. Alcohol dehydrogenase $(A D H)$ isoenzymes and aldehyde dehydrogenase $(A L D H)$ in the sera of patients with liver cancer. J Clin Lab Anal 2008; 22: 204-9. 